\title{
Developing Speaking Material Using Islamic contents in MA Salafiyah Kajen
}

\author{
Alfu Nikmah ${ }^{1}$ \\ ${ }^{1}$ Institut Agama Islam Negeri Kudus, Kudus, Indonesia \\ Contact: Alfu Nikmah $\bigotimes$ alfunikmah@stainkudus.ac.id
}

\begin{abstract}
This article tries to describe about the developing Islamic content textbook for speaking English. The method used in this article are developmental research and design instructional model for the design. The article is not to generate a theory or verify one. It attempts to develop English learning material for speaking skill using textbook containing Islamic contents at first semester of tenth grade senior high school. Some steps passed in developing the English vocabulary material; need analysis, design, development, expert validation, try out, revision, and final product. It could be as a proof that this material could be applied to the tenth grade students. And the result shows that Islamic content textbook for English speaking material could be applied to the tenth grade students in Madrasah Aliyah Salafiyah Kajen, Pati Central Java Indonesia.
\end{abstract}

\author{
KEYWORDS: \\ English learning materials; \\ speaking material \\ Islamic contents; \\ developmental research; \\ Islamic school.
}

\section{Introduction}

The national education system in Indonesia includes public and private schools under the Ministry of National Education (MONE) and Islamic schools/madrasahs (public and private) under the management of the Ministry of Religious Affairs (MORA). However, all schools offering the national curriculum are subject to standards set by MONE. The Islamic School Sub-sector has a central role to play in national education. Approximately 6 million children, representing nearly $15 \%$ of school enrolment, attend madrasahs (Rohmah, 2012, pp. 158-159).

Islamic school or madrasah is quite difference with public school. Though Islamic school follows national curriculum, it also develops curriculum by adding some lesson in student's study. Islamic subjects are included in the curriculum. It is relevant to the spirit of the school itself. Islamic school commits in inserting Islamic values in the learning. Moreover, some Islamic school or madrasah are equipped with Islamic boarding school (Pesantren), where students can live and learn much in religion subject. 
English as compulsory subject in Islamic school has the same curriculum with national curriculum. However English in Islamic school should be developed because of the need of learners. In learning process many teachers find some obstacles in teaching English. English as a language is not used for communication in daily life. Therefore it needs the appropriate strategies and good material to teach English that can meet the student's need in teaching English.

The students' needs are covered by curriculum. Curriculum must be designed on the bases on the needs of the learners and purpose of education. It can be made by the stakeholder of the school that involves teachers who are related to the learning. In the learning of foreign language, teachers find difficulties in the conveying the lesson that covers all the skill that must be mastered by students: writing, speaking, reading and listening. Meanwhile the system of education of Indonesia that holds the national examination as the final assessment forces the teachers to make up the material to meet graduation standard. This neglects the main goal of teaching foreign language in which the students have to communicate in English. Instead of speaking, the learning process focuses more on the reading, listening and writing to gain the goal of final examination.

Baley and Savage as cited on Celce-Murcia, Brinton, \& Snow (2014) said that the goal of language teaching is to improve the learner's ability to communicate in the target language. The learners should be able to integrate skills from beginning; a given activity might involve reading, speaking, listening and also writing. Speaking in a second or foreign language has been viewed as the most demanding of four skills. Speaking as the most demanding of four skills considered that speaking is a central skill.

Speaking is a central skill as quoted by bailey and Savage; speaking is an activity requiring the integration of many sub system. All these factors combine to make speaking a second or foreign language a formidable task for language learners. Yet for many people speaking is seen as the central skill (Celce-Murcia et al., 2014). As a central skill, speaking is considered to be a difficult skill. It needs some effort to courage someone or students to speak up. Speaking is productive skill that need bravery, confidents in application. Some students are lack in practicing because most of them afraid in making mistakes. According to Verghese in Raja and Selvi (2011, p. 40) there are so many factors affecting the process of learning a second language. They are attitude, self-confidence, and motivation, duration of exposure to the language, classroom conditions, environment, family background, and availability of competent teachers.

Meanwhile, Khajloo (2013, p. 53) mentions five problems in English teaching and learning. They are lack of interest and motivation, lack of 
concentration, students who join English course, the lack of the English teacher's proficiency and lack of repetition and frequent practice of students. For the lack of concentration, it is influenced by some factors. They are fatigue and insomnia, environment and family problems.

It can be observed that many students are not able to speak English though they have studied English for five years or more. Therefore, considering to phenomena happened. Madrasah Aliyah (MA) Salafiyah holds conversation class as a self-development subject. In this case the school has vision in developing English as language practiced in school environment. Conversation class was held to accommodate student in speaking English. Therefore the aim of English learning realized in communication field. Students were supported much in practical rather than theory.

For supporting material in speaking class, materials are important to develop. Instructional materials are indispensable in any learning activities, including in ELT program (Richards, 2013, p. 147). Instructional materials might be in the form of textbooks or course-books, video and audio tapes, computer software, visual aids, and so forth. Cunningsworth (1995) argues that textbooks are an effective resource for autonomous learning, an effective resource for presentation material, a source of ideas and activities, a reference source for students, a syllabus where they reflect pre-determined learning objectives, and support for less experienced teachers who have yet to gain confidence.

According to Hutchinson and Waters on Palupi (2017) explain that good materials will contain interesting texts, enjoyable activities that engage the learners' thinking capacities, opportunities for learners to use their existing knowledge and skills. They also state that good materials should provide a clear and coherent unit structure, which will guide teachers and learners through various activities in such a way as to maximize the chance of learning.

As an Islamic school, it is necessary to bring the Islamic content in the learning because it is related to the culture and also the need of the students. To make lively in learning English, it should be completed with right and good material. It is very needed in learning and teaching process. Teachers and also students need a material for their supplement in studying English. Moreover good material of English will lead to practice as Anderson said:

When word put together to communicate a meaning, a piece of text is created. When you speak or write to communicate a message, you are constructing the text. Creating a text requires us to make choices about the words we use and how we put them together. If we make right choices then we can communicate with others, our choices of words will depend on our purpose and our surrounding (context) (Anderson \& Anderson, 1997, p. 1). 
Based on Anderson and Anderson (1997) it can be inferred that, communication can run naturally based on the surrounding or culture itself. When someone conveying a message they will create based on the choices or the need that related to the culture or surrounding. Therefore constructing the text inserted with Islamic contents will meet the need of the students that learn in Islamic school.

Cortazzi and Jin (1999) divide three information types with regard the textbooks:

1. Source culture materials it means that inserting learners' culture into the teaching content.

2. Target culture material that using the culture of the country where English is used as the first language

3. International target culture materials that use the cultures of various English speaking countries and those who do not use as international language.

The material development in supporting students and teachers' learning can be accommodated with Islamic contents that suitable to the surrounding. Speaking text material will be the guidance book to the teachers and students in conversation class.

Based on Rohmah (2012) said that using textbooks or course-books containing Islamic values can be done when they are available in the market. However, up to 2012 course-books for ELT in pesantren and madrasah are not available yet in Indonesian book stores. The material text book is very rare in the bookstore. According to Rohmah (2010) the only available 'course book' with suitable Islamic contents is 'English in Context (EIC).' This book is still in the form of draft copy intended as a resource book developed by trainers under the Islamic Schools English Language Project (ISELP). This book was designed by the ISELP trainers as an effort to minimize the poor materials being used by English teachers in the pesantren. The main purpose was to provide the pesantren students with opportunities to talk about themselves and their lives in the pesantren with a significant focus on speaking and listening.

According to Rohmah (2010, p. 160) the Islamic contents might be included in the course-books in two ways: First, Straightforwardly, that is, mentioning the Islamic topics explicitly, such as, 'How to do wudlu', 'Muslim to Muslim'. In this case, the title of the unit shows the Islamic messages openly so teachers as well as students can see and understand the Islamic messages easily. Second, inclusively, that is, including the Islamic messages in the materials indirectly through pictures, names, building, language activities, messages, etc. Unit title, such as, 'Can you keep the floor clean, please?', 'Daily activities,' including Muslims' activities are among the examples of the indirect 
inclusion of Islamic messages indirectly. The use of Muslim's names, for instance, Ahmad, Fathimah, Lathifah, Umar, Hakim, Azizah, Ali, Luthfia, might help the Muslim students express themselves more conveniently because they might feel that their life is linked to the books.

Based on the background and also the limited material text book inserted with Islamic values, the researcher conducted research and development by creating text inserted with Islamic context aimed to developing speaking material of conversation class. By developing material has intended to developing material to help teachers' and students' learning and improve students' speaking ability. Moreover it also contribute developing material according to the need of the students.

\section{Method}

The type of research that was conducted by the researcher is developmental research. I used material development model adapted from Hyland's (2003). Hyland (2003, p. 57) points out nine stages They are: considerations of learning context, establishment of course goal and objectives, planning syllabus, devising unit of works and lessons, creation or evaluation and selection of materials, teaching the course and evaluation of the learners. The steps can be seen from the scheme as follow:

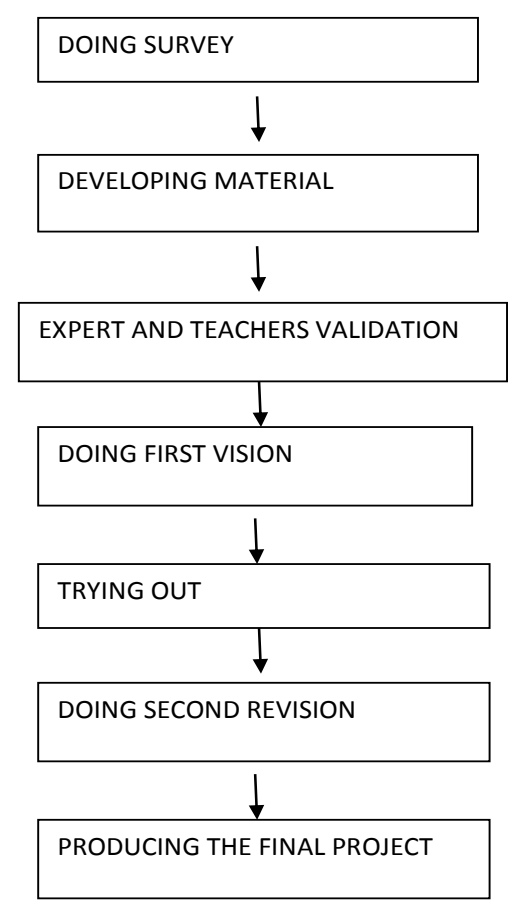

Figure 1 textbook developing step by step

(Hyland, 2003) 


\section{Discussion}

There are seven steps in conducting research. The following will be explained in detail:

\section{Survey}

This step was used to obtain the information of the learners' characteristics and needs in learning English. This step was used as the basis of the next stage of the study. In this stage, I observed English teaching and learning process in the classroom. I also interviewed the teacher and students to get the information about students' need and students' characteristic. Based on the result of the interview, I made an analysis that the students were lack of motivation in speaking. The material was too general and it didn't relate to students' culture. After doing a survey, I concluded that English teacher had to use the interesting media and materials in order to improve students' motivation in learning English.

In this step, I tried to observe the problems that students face in mastering speaking skill. After doing observation and also interview with teachers and also student I continued to make mapping. Developing material for tenth grade of Islamic Senior High School Students needs mapping. It is for planning during teaching -learning process combined with educational calendar. The content's standard consists of standard of competence, basic competence, language skill and number of meeting.

After mapping the content standard, I created syllabus and lesson plant based on standard competence and basic competence. These are standard competence and basic competence to construct syllabus.

a. Standard Competence

Listening 1: Understanding transactional and interpersonal communications in context of daily life

Speaking 3: Expressing meaning of transactional and interpersonal communications in the context of daily life

b. Basic competence:

1. To respond transactional and interpersonal communication, both formally using simple, accurate, fluent, and acceptable oral language in the context of daily life and involving the functions of gratitude, complimenting and congratulating.

2. To express meaning in formal and informal transactional and interpersonal conversation using simple spoken language accurately, fluently, and understandably in the form of gratitude, complimenting and congratulating. 


\section{Developing Material}

After doing mapping, I constructed syllabus and lesson plan. Next I constructed textbook material. I called my text book "let's speak". It consist of students and teachers' book completed with CD. The materials were taken and arranged from the syllabus. I also inserted the Islamic contents to correlate the material with the basic of school as Islamic senior high school. The book consisted of some materials such as conversational text, listening section, grammar focus and development of vocabulary and pronunciation.

Conversation text inserted with Islamic content is new material to create the appropriate and interesting material for Islamic Senior High School. The text covers Islamic contextual that is daily used by student for example: reciting Qur'an, praying, fasting, and doing the good things restraining the bad ones and also jihad, the correct definition of Jihad.

The Islamic content was inserted (Table 1) in the production of the text which is suited with basic competence and competence standard. For chapter I (one) it covered standard and basic competence about mastering listening and speaking to express the expression using compliment, congratulation and gratitude. It can be seen in Table.

Table 1 dialog on the textbook

\begin{tabular}{|c|c|}
\hline Actor & Dialogue \\
\hline Rahma & $\begin{array}{l}\text { What a beautiful voice, Amir. You are really good in reading qur'an. You } \\
\text { must be the winner in this competition. }\end{array}$ \\
\hline Amir & $\begin{array}{l}\text { Thanks, Rahma. But Im'not sure to be the winner because they are many } \\
\text { others have beautiful voice in reading Qur'an. }\end{array}$ \\
\hline Rahma & Mir, do you often read Qur'an? It seems that you read by heart. \\
\hline Amir & $\begin{array}{l}\text { Yeah, I always read Qur'an after having magrib praying. What about you } \\
\text { Rahma? }\end{array}$ \\
\hline Rahma & $\begin{array}{l}\text { Hmmm....I feel so embarrassed, I feel so embarrassed, I read qur'an just } \\
\text { once a week on Thursday night. }\end{array}$ \\
\hline Amir & It's ok, but the more you read qur'an the better you are, right? \\
\hline Rahma & $\begin{array}{l}\text { I see, I will do what didi you say then. Hey listen....I heard your name called } \\
\text { by the jury, You are the first winner Amir. }\end{array}$ \\
\hline Amir & Subhanallah, Alhamdulillah...I don't believe it. \\
\hline Rahma & Congratulation on your winning mir, I really proud of you. \\
\hline Amir & Thanks Rahma, I'll go to the stage. \\
\hline Rahma & Yeah, be hurry..... \\
\hline
\end{tabular}

Based on the text, it can be found some expressions inserted with Islamic message. The text consisted congratulation expression "Congratulation on your winning Mir, I really proud of you". The theme inserted with Islamic message that expressed about the winning of reading Qur'an. Moreover the conversation text used the Islamic name, Amir and Rahma. 


\section{Expert Validation}

After finishing mapping, creating syllabus, lesson plan and developing text book material, the materials were validated by expert and teachers. The forms of experts and teachers validation were altered and taken from (Celce-Murcia et al., 2014, p. 425; Richards, 2013, p. 247).

There are two experts and two English teachers who did validation in developing English teaching material. The result of the expert and teacher validation in table 2.

Table 2 Expert validation result

\begin{tabular}{lcccccc}
\hline \multirow{2}{*}{ Product } & \multicolumn{5}{c}{ The average of Validation } \\
\cline { 2 - 7 } & \multicolumn{2}{c}{ Expert } & \multicolumn{3}{c}{ Teacher } & Average \\
\cline { 2 - 7 } & 1 & 3,9 & 3,23 & 3,67 & 3,59 \\
\hline Student textbook & 3,56 & 4 & 3,24 & 3,8 & 3,36 \\
\hline Teacher textbook & 2,4 & 3,6 & 3 & 3,83 & 3,35 \\
\hline CD Let's speak & 3 & &
\end{tabular}

The table above shows that the average of the experts and teacher's validation on the conversation text book for both student and teacher's book were 3.59 and 3.36. It indicated that the product was appropriate with the criteria of the material standard. The judgment and suggestions from the experts and the teachers were implemented to revise the product then.

Furthermore, according to the average scores showed in Table 2, the experts and teachers generally respected that the developed material was good in order to teach speaking competence. As a result, they recommended that after being revised, I was able to do the tryout.

\section{First revision}

In the respond to expert and teachers' comments, judgment, and suggestion. I did the first revision on my material. The first expert commented on the contents of the text book. The contents of textbook should be added some more complicated materials corresponded to student's level. The first expert also gave a comment about the technical of writing. The material should be given a well-organized order and instruction to get easy in understanding the book.

Another revision was from teacher (Table 3) proposed that there should be more pictures illustrated the activities. It was aimed to attract the readers or students toward the book and also to get clear by seeing the picture dealing with ordered and given instruction. First revision was adding the text with another conversation about fasting. 
Table 3 dialogue revision

\begin{tabular}{|c|c|}
\hline Actor & Dialogue \\
\hline Ahmad & Assalamu'alaikum Ali, how's the things Ali? \\
\hline Ali & Waalaikum salam, fine, thank you \\
\hline Ahmad & Wow...you look great in your moslem shirt Ali.. \\
\hline Ali & oh, thanks...., my mother gave it foar my birthday last week. \\
\hline Ahmad & we'll have fasting month next week Ali.. \\
\hline Ali & yeah...so Ramadan is the tenth of Islamic year isn't it? \\
\hline Ahmad & $\begin{array}{l}\text { of course not, it is the ninth. You know Fasting in the month of Ramadan } \\
\text { is one of five pillars of Islam }\end{array}$ \\
\hline Ali & yes, we as moslems are obligated to fast during Ramadan \\
\hline Ahmad & $\begin{array}{l}\text { By the way, do you remember what verse tells us about obligation of } \\
\text { fasting? }\end{array}$ \\
\hline Ali & I do, It is Al-Baqara verse 183. \\
\hline Ahmad & I have a nine year old brother. Does he has to fast? \\
\hline Ali & oh certainly not, He is not adult yet. \\
\hline Ahmad & Do you know those who are exempt from fasting? \\
\hline Ali & $\begin{array}{l}\text { Surely I do. They are: the insane, the chronically sick, and elderly people, } \\
\text { the pregnant woman and so on }\end{array}$ \\
\hline Ahmad & And who must fast, then? \\
\hline & Those men and woman who are sane, able, adult and resident. \\
\hline Ahmad & what is meant by sane? \\
\hline Ali & if you are physically and mentally fit, you are sane. \\
\hline Ahmad & an adult? \\
\hline Ali & it is the age of puberty, normally about fourteen. \\
\hline Ahmad & what about resident? \\
\hline Ali & $\begin{array}{l}\text { a resident is the one supposed to be present at a permanent settlement, } \\
\text { like a home town, a farm and so on. }\end{array}$ \\
\hline $\begin{array}{l}\text { Ahmad } \\
\text { Ali }\end{array}$ & $\begin{array}{l}\text { nice chatting Ali..., thanks a lot... } \\
\text { you're welcome. }\end{array}$ \\
\hline
\end{tabular}

Second revision is adding picture in conversation text (Figure 2). As a result, they recommended that after the draft was revised, then I could continue to make a tryout.

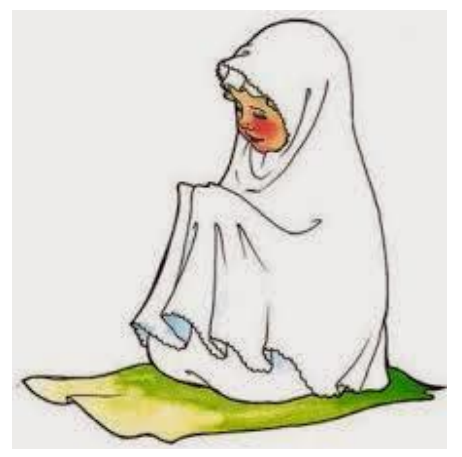

Figure 2 Picture added in conversation text 
Hasan : What time is it Amir?

Amir : Uhm...it is a quarter to seven?

Hasan :Oh my god, I haven't prayed Maghrib yet. Will you help me?

Amir :Certaintly, What is it San?

Hasan :Please finish this typing while I'm praying. I'll be back in ten minutes

Amir : all right

Hasan : Thank you very much

Amir : It's All right

\section{Try out}

Next step in developing material is try out. Try out was conducted for four days, Tuesday to Friday. It included evaluation in the four meeting. Every meeting took two hours $\left(2 \times 40^{\prime}\right)$. The activities were scheduled (Table 4$)$.

Table 4 the activities

\begin{tabular}{llll}
\hline Dates & Topics & Time & RPT \\
\hline 22 may 2017 & Compliment & $80^{\prime}$ & $70^{\prime}$ \\
23 may 2017 & Compliment and congratulation & $80^{\prime}$ & $70^{\prime}$ \\
29 June 2017 & Thanking & $80^{\prime}$ & $70^{\prime}$ \\
30 June 2017 & Evaluation & $80^{\prime}$ & $70^{\prime}$ \\
\hline
\end{tabular}

In Try out, I duplicated the materials that has been revised. I handed them to Mrs. Erni Shofa Nugraha which were distributed them to the students. Tryout activities were carried out for four meeting and each meeting consisted of two hour of learning hours. The result of tryout showed that there are some improvement in students' speaking skill. The average score of examination was 78,76 . Though the result of this study was not strongly agreed since the design of this study used, it could be seen that the teaching using this material leads to the improvement of students' speaking competence if it was compared with the existing score document. Moreover, the use of Islamic content in speaking materials gave a different atmosphere in learning and became a good option which eased them to comprehend the learning materials. It can be seen from this score of conversation test (Table 5).

After doing tryout, teacher gave some opinions to improve the textbook by giving vocabulary section after learning conversation text. It was important to improve students' mastery in vocabulary and pronunciation (Table 6). 
Table 5 Conversation score

\begin{tabular}{|c|c|c|c|c|c|c|c|}
\hline \multirow[t]{2}{*}{ CODE } & \multicolumn{4}{|c|}{ SCORE } & \multirow{2}{*}{$\begin{array}{l}\text { Total } \\
\text { score }\end{array}$} & \multirow[t]{2}{*}{ Score } & \multirow[t]{2}{*}{ Note } \\
\hline & Pronunciation & Vocabulary & Structure & Fluently & & & \\
\hline L.1 & 3 & 4 & 3 & 4 & 14 & 87.5 & Pass \\
\hline L.2 & 4 & 4 & 3 & 4 & 15 & 93.75 & Pass \\
\hline L.3 & 3 & 3 & 2 & 3 & 11 & 68.75 & Pass \\
\hline L.4 & 3 & 3 & 2 & 3 & 11 & 68.75 & Pass \\
\hline L.5 & 4 & 4 & 3 & 4 & 15 & 93.75 & Pass \\
\hline L.6 & 3 & 3 & 3 & 3 & 12 & 74 & Pass \\
\hline L.7 & 3 & 3 & 3 & 3 & 12 & 75 & Pass \\
\hline L.8 & 3 & 3 & 3 & 4 & 13 & 81.25 & Pass \\
\hline L.9 & 3 & 3 & 3 & 3 & 12 & 75 & Pass \\
\hline L. 10 & 3 & 3 & 3 & 3 & 12 & 75 & Pass \\
\hline L.11 & 4 & 3 & 3 & 3 & 12 & 75 & Pass \\
\hline L.12 & 3 & 3 & 3 & 3 & 12 & 75 & Pass \\
\hline L.13 & 3 & 3 & 3 & 3 & 12 & 75 & Pass \\
\hline L.14 & 3 & 3 & 3 & 4 & 13 & 81.25 & Pass \\
\hline L.15 & 3 & 3 & 3 & 3 & 12 & 75 & Pass \\
\hline L.16 & 3 & 2 & 3 & 3 & 11 & 68.75 & Pass \\
\hline L.17 & 4 & 3 & 3 & 4 & 14 & 87.5 & Pass \\
\hline L. 18 & 3 & 3 & 3 & 3 & 12 & 75 & Pass \\
\hline L.19 & 3 & 3 & 3 & 3 & 12 & 75 & Pass \\
\hline L.20 & 3 & 2 & 3 & 3 & 11 & 68.75 & Pass \\
\hline L. 21 & 3 & 3 & 3 & 3 & 12 & 75 & Pass \\
\hline L.22 & 3 & 3 & 3 & 3 & 12 & 75 & Pass \\
\hline L. 23 & 3 & 2 & 3 & 3 & 11 & 68.75 & Pass \\
\hline L.24 & 3 & 3 & 3 & 4 & 13 & 81.25 & Pass \\
\hline L.25 & 3 & 2 & 3 & 3 & 11 & 68.75 & Pass \\
\hline L.26 & 3 & 4 & 4 & 4 & 15 & $93 . .7575$ & Pass \\
\hline L.27 & 3 & 3 & 3 & 3 & 12 & 75 & Pass \\
\hline L.28 & 3 & 3 & 3 & 3 & 12 & 75 & Pass \\
\hline L.29 & 3 & 4 & 4 & 4 & 16 & 93.75 & Pass \\
\hline L.30 & 3 & 4 & 3 & 4 & 14 & 87.5 & Pass \\
\hline Total & 95 & 92 & 91 & 99 & 376 & 23335 & \\
\hline Average & 3.16 & 3.06 & 3.03 & 3.3 & & 77.76 & \\
\hline
\end{tabular}

Table 6 Result of second revision

\begin{tabular}{|c|c|c|}
\hline Part of revision & Before revision & After revision \\
\hline Part I & $\begin{array}{l}\text { After the text, there is no } \\
\text { vocabulary core and word } \\
\text { transcription }\end{array}$ & 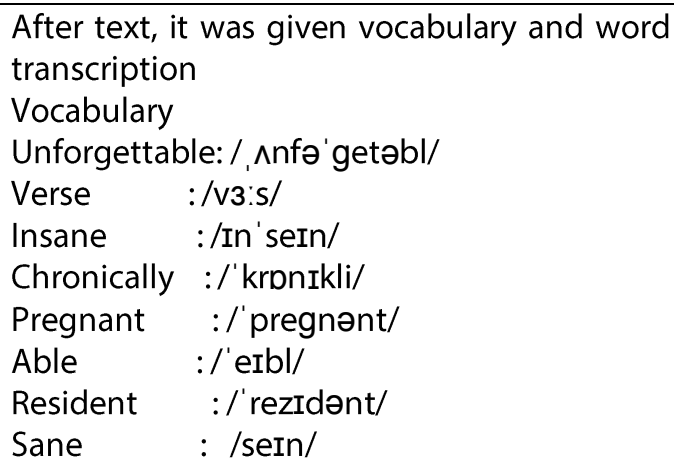 \\
\hline
\end{tabular}

Final Product

After having final revision, I created the fixed learning material to the students. The material passed the essential steps by acquiring several improvements from the expert, teachers and students. Next, I edited and revised material in order to generate the better product. The final Islamic content of English 
Speaking material were finalized with some additional illustrations. Then the fixed material was ready to be reprinted, demonstrated, published and distributed to the public.

\section{Conclusion}

Learning English has spread in every education institutions. It happens in Islamic school or madrasah that commits to national curriculum. Though it needs material development to meet the students' need. The need relates to the culture and environment. Islamic schools hold both national and local curriculum therefore material development should be created. Islamic contents should be inserted in materials to get the appropriate atmosphere. Material development in English subject that has been produced inserted Islamic contents. It is developed to meet the students' need that interact the Islamic atmosphere in the school. The speaking material development was created to encourage students to speak English in the school. Therefore English is learnt practically as language.

\section{References}

Anderson, M., \& Anderson, K. (1997). Text Types in English. Macmillan Education Australia.

Celce-Murcia, M., Brinton, D. M., \& Snow, M. A. (2014). Teaching English as a Second Or Foreign Language. National Geographic Learning.

Cortazzi, M., \& Jin, L. (1999). Cultural Mirrors: Materials and Methods in the EFL clssroom. In E. Hinkel (Ed.), Culture in Second Language Teaching and Learning. Cambridge University Press.

Cunningsworth, A. (1995). Choosing Your Coursebook. Max Hueber Verlag.

Hyland, K. (2003). Second Language Writing. Cambridge University Press.

Khajlo, A. I. (2013). Problems in Teaching and Learning English for Students. International Journal of Engineering Research (Vol. 7).

Palupi, F. (2017). Developing English Learning Material for Speaking Skill Based on ADDIE. Premise Journal, 6(1), 29-41. http://doi.org/10.24127/pj.v6i1.805

Raja, Dharma and Selvi, K. (2011). Causes of Problems in Learning English as A Second Language as Perceived by Higher Secondary Students. I-Manager's Journal on English Language Teaching, 1(4), 40-45.

Richards, J. C. (2013). Materials Development and Research: Towards a Form focused Perspective. In S. Fotos \& H. Nassaji (Eds.), Form-Focused Instruction and Teacher Education - Oxford Applied Linguistics. Oxford University Press.

Rohmah, Z. (2010). English Language Training for Islamic Schools (ELTIS): Trainees' Outlook. In CamTESOL Conference (pp. 117-129).

Rohmah, Z. (2012). Incorporating Islamic Messages in the English Teaching in the Indonesian Context. International J. Soc. Sci. \& Education (Vol. 2). 